\title{
Lack of aminoacids in mouse hepatocytes in culture induces the selection of preneoplastic cells
}

\author{
Andrea N Chisari ${ }^{* *}$, Stella M Echarte ${ }^{1}$, Enrigue Podaza ${ }^{1}$, Isabel Fabregat ${ }^{2}$ \\ From Metabolism, diet and disease \\ Washington, DC, USA. 29-31 May 2012
}

Protein malnutrition occurs when there is insufficient protein to meet metabolic demands. Previous works have indicated that cycles of protein fasting/refeeding enhance the incidence of early lesions during chemical carcinogenesis in rat liver. In mammals, protein malnutrition causes high susceptibility to infection diseases and cancer. In liver, both caloric and proteic malnutrition cause severs metabolic changes [1].

The general objective of this work was to study the effect of aminoacids (Aa) deprivation on the proliferation and survival of hepatocytes, to understand its possible involvement in the generation of preneoplastic stages in the liver.

Experimental procedures: cell line derived from newborn mice hepatocytes (Parental cells=Par) [2] were cultured in complete medium, or aminoacid-starved medium (PM=private medium).

When hepatocytes are cultured in the absence of Aa, the cells detaches and die through apoptosis. After $72 \mathrm{~h}$ of culture with PM the few surviving cells were incubated with complete medium. After changing the medium, cells began to proliferate and expanded (Selected Cells=Sel).

Sel cells showed a significant higher proliferation rate than the Par ones. This conclusion was confirmed by studying the incorporation of $[3 \mathrm{H}]$-Thymidine as an analysis of DNA synthesis. In the presence of different concentrations of Fetal Bovine Serum, indicating that response to extracellular mitogens is enhanced in these cells. The response to the Transforming Growth Factorbeta (TGF- $\beta$ ), a physiological inducer of hepatocyte apoptosis whose concentration is elevated in liver tumors to counteract the abnormal growth of preneoplastic cells $[3,4][5]$, is altered in Sel cells. Both TGF- $\beta$-induced

'Biological Research Institute y Chemical Department, Mar del Plata National University, Mar del Plata, CP7600, Argentina

Full list of author information is available at the end of the article decrease in cell viability and caspase- 3 activation were attenuated in Sel when compared to the parental cells.

Both p-ERKs and p-AKT levels were much higher in Sel cells than in the Par ones. Downstream AKT signals, such as p70S6 and GSK3 were also higher phosphorylated in Sel cells. Interestingly, showed increased levels of p-SRC, which correlated with increase in the levels of phosphorylation of the EGF receptor (EGFR). These results indicate that the EGFR/SRC pathwaymight be overactivated in Sel cells. Sel cells expressed higher levels of EGFR ligands, such as TGF- $\alpha$ and HB-EGF; semiquantitative RT-PCR analysis clearly revealed that both ligands were overexpressed in Sel cells, when compared with normal hepatocytes. Moreover it is noteworthy that MAPK proteins c-JNK and p38, which remained increased in Sel cells.

In conclusion, results presented indicate that it is possible to isolate in vitro a population of hepatocytes that are able to survive in the absence of $\mathrm{Aa}$, which has higher capacity to proliferate, showing a preneoplastic phenotype. This could explain why the alternately deprivation of proteins in diet could induce hepatocarcinogenesis susceptibility.

\footnotetext{
Author details

${ }^{1}$ Biological Research Institute y Chemical Department, Mar del Plata National University, Mar del Plata, CP7600, Argentina. ${ }^{2}$ Biological Clues of the Invasive and Metastatic Phenotype Group, Bellvitge Biomedical Research Institut (IDIBELL), L'Hospitalet de Llobregat, Barcelona, Spain.

Published: 1 June 2012

References

1. Caballero VJ, Mendieta JR, Giudici AM, Crupkin AC, Barbeito CG, Ronchi VP, Chisari AN, Conde RD: . Journal of Physiology and Biochemistry 2011, 67:43-52.

2. Gonzalez-Rodriguez A, Escribano O, Alba J, Rondinone CM, Benito M, Valverdealcz AM: . Journal of Cellular Physiology 2007, 212:76-88.
} 
3. Caja L, Ortiz C, Bertran E, Murillo MM, Miro-Obradors MJ, Palacios E, Fabregat I: . Cellular Signalling 2007, 19:683-694.

4. Sancho P, Fabregat I: . Journal of Biological Chemistry 2010, 285:24815-24824.

doi:10.1186/1753-6561-6-S3-P13

Cite this article as: Chisari et al:: Lack of aminoacids in mouse

hepatocytes in culture induces the selection of preneoplastic cells. BMC

Proceedings 2012 6(Suppl 3):P13.

Submit your next manuscript to BioMed Central and take full advantage of:

- Convenient online submission

- Thorough peer review

- No space constraints or color figure charges

- Immediate publication on acceptance

- Inclusion in PubMed, CAS, Scopus and Google Scholar

- Research which is freely available for redistribution

Submit your manuscript at www.biomedcentral.com/submit 